University of Nebraska - Lincoln

DigitalCommons@University of Nebraska - Lincoln

Anthropology Faculty Publications

Anthropology, Department of

2008

\title{
The Role of Basketry in Early Holocene Small Seed Exploitation: Implications of a ca. 9,000 Year-Old Basket from Cowboy Cave, Utah
}

Phil R. Geib

University of Nebraska - Lincoln, pgeib2@unl.edu

Edward A. Jolie

University of New Mexico

Follow this and additional works at: http://digitalcommons.unl.edu/anthropologyfacpub

Part of the Archaeological Anthropology Commons, and the Social and Cultural Anthropology Commons

Geib, Phil R. and Jolie, Edward A., "The Role of Basketry in Early Holocene Small Seed Exploitation: Implications of a ca. 9,000 YearOld Basket from Cowboy Cave, Utah" (2008). Anthropology Faculty Publications. 138.

http://digitalcommons.unl.edu/anthropologyfacpub/138

This Article is brought to you for free and open access by the Anthropology, Department of at DigitalCommons@University of Nebraska - Lincoln. It has been accepted for inclusion in Anthropology Faculty Publications by an authorized administrator of DigitalCommons@University of Nebraska Lincoln. 


\title{
THE ROLE OF BASKETRY IN EARLY HOLOCENE SMALL SEED EXPLOITATION: IMPLICATIONS OF A CA. 9,000 YEAR-OLD BASKET FROM COWBOY CAVE, UTAH
}

\author{
Phil R. Geib and Edward A. Jolie
}

\begin{abstract}
Despite ranking at the low end of the continuum in net caloric benefit relative to other foods, small seeds assumed great dietary importance in many parts of the world, including western North America. In a series of publications, Adovasio (1970a, 1974, 1980, 1986) argued that coiled basketry technology was invented in the eastern Great Basin during the early Holocene as a specialized food-processing technique. Coiled baskets are indeed useful for collecting and processing seeds, but it does not necessarily follow that they were originally designed for this purpose. A whole basket recently discovered at Cowboy Cave in southeastern Utah returned an AMS radiocarbon assay of $7960 \pm 50$ B.P., making it currently the earliest directly dated coiled basket from the Americas. This basket is not a parching tray and likely had nothing to do with harvesting seeds. We discuss the implications of this find with regard to tracking the temporal spread of coiled basketry technology in western North America and the role of coiled and twined forms in the initiation of small seed exploitation. Coiled and twined baskets for small seed processing may result from reconfiguration of existing technologies to create novel forms suited to a new food exploitation strategy.
\end{abstract}

A pesar de localizarse en la parte inferior del rango calórico relativo a otros alimentos, pequeñas semillas asumieron un papel de gran importancia dietética en muchas partes del mundo, incluyendo el oeste de Norteamérica. En una serie de publicaciones, Adovasio (1970a, 1974, 1980, 1986) señala que la tecnología de cestería tejida en forma de espiral fue inventada en la parte oriental de la Gran Cuenca norteamericana durante el Holoceno temprano específicamente para secar semillas. De hecho, las cestas en espiral son útiles para el procesamiento de la semilla, pero no necesariamente fueron originalmente diseñadas para este propósito. Recientemente, una cesta completa fue descubierta en una cueva (Cowboy Cave) en el sudeste de Utah que arrojó un análisis de radiocarbono de AMS $7960 \pm 50$ B.P., haciéndola actualmente la cesta tejida en espiral más antigua analizada directamente en las Américas. Esta cesta no cumplía una función para secar ni probablemente tampoco para cosechar semillas. Hablamos de las implicaciones de este hallazgo en relación con el seguimiento de la expansión temporal de la tecnología cestera tejida en espiral en el suroeste estadounidense, y los papeles de estas formas espirales y trenzadas en el inicio de la explotación de pequeñas semillas. Cestas tejidas en espiral y trenzadas para el procesamiento de semillas pequeñas podrían haber resultado de la reconfiguración de tecnologías ya existentes para crear nuevas formas estratégicas en la explotación de nuevos alimentos.

$\mathrm{R}$

elative to many other foods, the exploitation of small seeds for sustenance is hardly profitable. Studies of the costs and benefits of small seeds have consistently demonstrated that such resources rank at the low end of the continuum in net caloric benefit (e.g., Barlow and Metcalfe 1996; Cane 1989; Gremillion 2004; O'Connell and Hawkes 1981; Simms 1985, 1987; Wright 1994). Despite this, such low-ranked seeds eventually assumed great dietary importance in many parts of the world, including the Great Basin and the Southwest of North America. Although small seed resources are costly to procure and process, they can and have become very important under the right ecological and social conditions. As a result, the addition of small seeds to the diet of prehistoric hunter-gatherers is commonly seen as a key adaptive shift away from focal economies (Cleland 1966:42-45) to ones that were far more diverse-Flannery's (1969) "broad spectrum rev-

Phil R. Geib - Department of Anthropology, University of New Mexico, 1601 Tijeras Ave. NE, Apt. 30, Albuquerque, NM 87106 (pgeib@unm.edu)

Edward A. Jolie - Department of Anthropology, University of New Mexico, MSC01-1040, 1 University of New Mexico, Albuquerque, NM 87131-0001 (edjolie@unm.edu) 
olution." This does not imply that plant foods were never important prior to the close of the Pleistocene, rather that small seeds evidently became highly attractive economically during the Holocene (Coulam 1988; Grayson 1993; O'Connell et al. 1982:234; Van Ness and Hansen 1996).

Part of the tool kit necessary for exploiting small seeds are grinding tools, the metates and manos that archaeologists have recovered from most sites occupied by early Holocene foragers of the Great Basin and Colorado Plateau. Grinding tools are typically seen as an indelible marker of broad spectrum hunting and gathering (Jennings 1978:11) because it is through their use that seeds can be transformed into flour, which is an essential preparatory step for adequate nutrition absorption and can increase palatability (Adams 1999; Stahl 1984, 1989). We argue that baskets suitable for winnowing and parching constitute a more fundamental component of the technology for small seed exploitation. The very cost/benefit calculations of post-encounter return rates for small seeds provided by Simms (1987) and others (Barlow and Metcalfe 1996; Jones and Madsen 1989) all involve baskets or basket-like containers similar to those documented ethnographically in the Great Basin (Fowler and Dawson 1986) and California (Elsasser 1978). Efficient exploitation of small seeds depends on some means to catch or concentrate these items in mass rather than as individuals, for winnowing to remove chaff and other inedible debris, and for eventual parching to increase nutritional value. It requires a technological solution that is preferably light, portable, and easily used. Consider that the caloric return rates calculated for seeds harvested with containers are low both absolutely and relative to other resources of the Colorado Plateau and Great Basin (Simms 1985:Tables 3 and 4).

We maintain that the need to exploit small seeds created the requisite selective environment for the widespread application of basketry for this purpose. But, was coiled basketry innovated to meet this need as Adovasio (1970a, 1974, 1980, 1986) has argued? Or, alternatively, did seed processing baskets result from reconfiguration of an extant technology for this new purpose? It is common to read about technologies or behaviors having been innovated in prehistory as adaptive solutions to particular problems or needs, such as coiled basketry for seed exploitation, but redesign of an existing technology is worth considering (see Bock [1959] and Gould and Vrba [1982] for application of this concept in biology).

To explore the role of basketry in the shift to a generalist subsistence economy we first examine evidence for the antiquity of small seed processing in western North America and its relationship to basketry technology. We then describe a newly discovered and directly dated basket from Cowboy Cave in southeastern Utah that constitutes what is currently the earliest directly dated coiled basket from the Americas. This recent find has implications for (1) refining the early history of Cowboy Cave's use, (2) helping us track the temporal spread of coiled basketry technology in the Southwest and Mesoamerica, and (3) exploring the role of coiled and twined basketry in intensive small seed exploitation on the Colorado Plateau and beyond.

\section{Baskets and the Timing of Intensive Small Seed Use in Western North America}

In a recent study investigating small seed consumption at Danger Cave, Utah (Jennings 1957) (Figure 1), Rhode et al. (2006) demonstrated that seeds did not become a dietary staple until after 8700 B.P. They did this by determining the age of human feces containing seeds, the age of the initial layers of pickleweed (Allenrolfea occidentalis) chaff in the deposits, and the stratigraphic distribution of grinding tools. Basketry is a potentially corroborating data set for their case since the early deposits at the site, the DI layers, yielded no basket fragments. This lack of DI basketry might be a preservation problem, but the absence accords well with Rhode et al.'s argument. Rudy (1957) lists seven basket fragments from the overlying DII layers. These have a potentially wide temporal distribution, as old as 10,100 B.P. or as recent as 7500 B.P., according to current dates and their interpretation (Rhode et al. 2006:330, Table 2). Given the evidence for intensive small seed use by 8600 B.P., we expect that the baskets conducive to processing seeds are minimally this old unless the seeds were collected by some other means, such as the wooden trays used by Australian aborigines (e.g., Cane 1989). All of the DII basket fragments were constructed by the twining technique in which active horizontal elements (the wefts) twist around passive vertical elements (the warps) (Figure 2). Only 


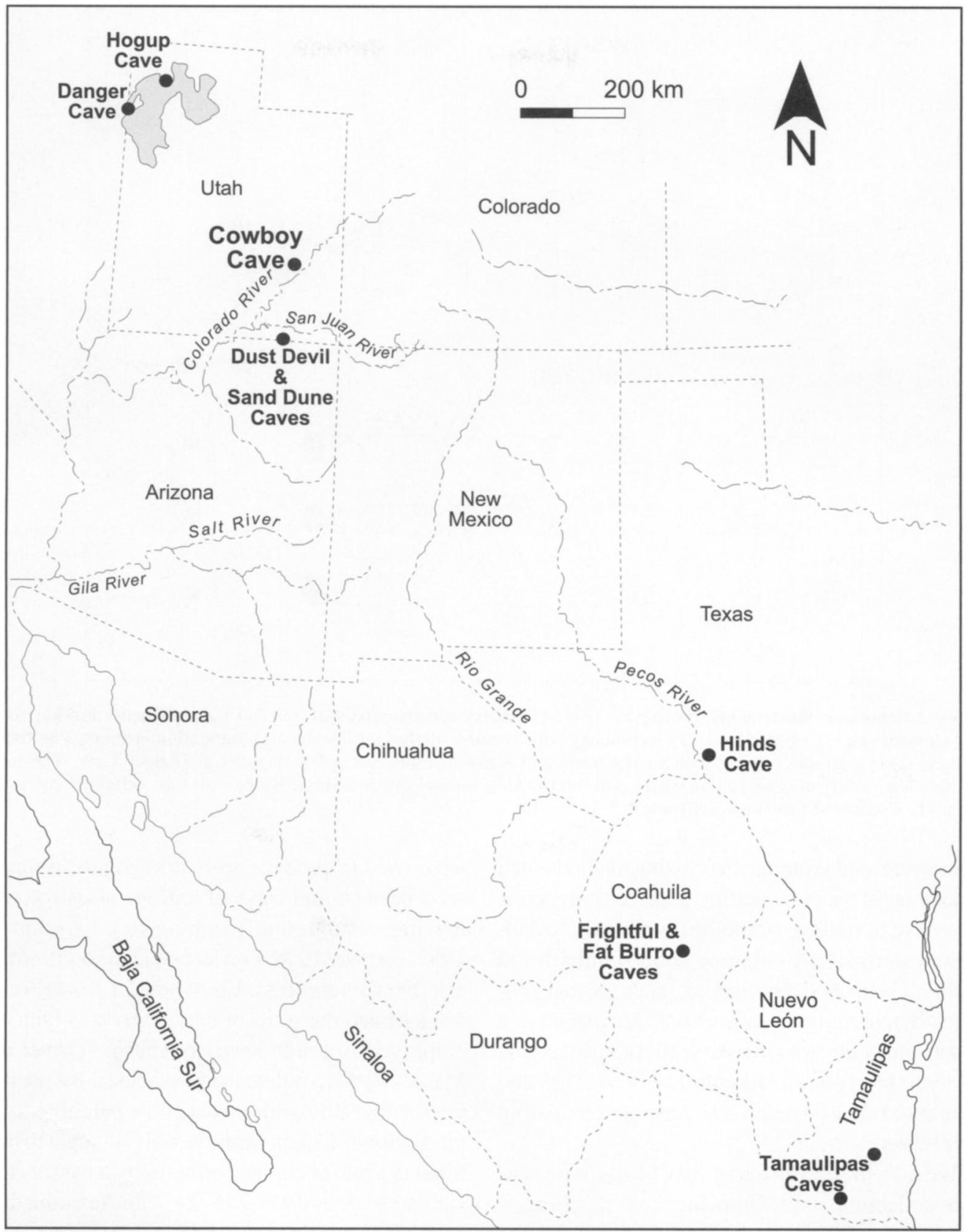

Figure 1. Map of the greater North American Southwest, including part of the Great Basin, showing Cowboy Cave and the other sites mentioned in the text that have produced early Archaic coiled basketry.

three of the DII basket fragments are close twined and hence potentially suitable for seed collecting and processing. At least one of these pieces (Rudy 1957:Figure 219) appears charred, if not accidentally, possibly from use as a parching tray, and this calls attention to another essential role of basketry in a small seed adaptation - that of parching.
Although the precise procedures and equipment vary across cultures, there are actually only a few basic techniques for processing seeds, each of which has its own set of nutritional implications (Stahl 1984, 1989). Mechanical processing methods entail the first steps taken to eliminate inedible or indigestible plant parts, often through threshing, 


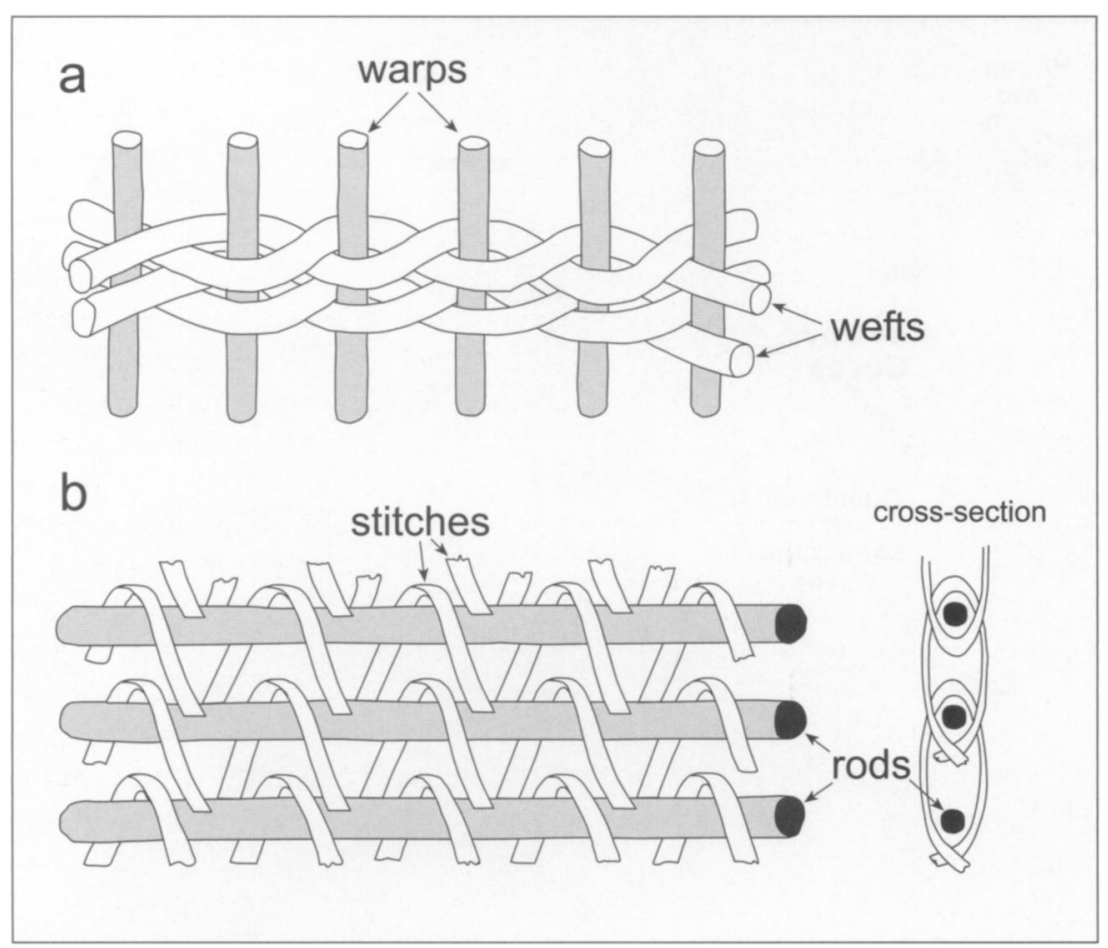

Figure 2. Schematic illustrations showing (a) twined basketry construction with vertical warp elements and horizontal weft elements and (b) coiled basketry technology with vertical stitches and horizontal foundation element. The twined example is close simple twining with s-twist wefts and is documented in the DII deposits at Danger Cave. The coiled example is a variety of close coiling where non-interlocking stitches pierce a single whole rod; this technique represents the newly discovered Cowboy Cave basket.

winnowing, and grinding. Processing methods such as soaking in water or heating (e.g., roasting, boiling) serve to remove or minimize potentially dangerous toxins and enhance food's nutritional quality. Controlled dry heating, such as that produced by parching when hot coals are placed in a basket and gently tossed with seeds or nuts, has the ability to increase the digestibility of starches and proteins while also helping to separate seeds from their husks. ${ }^{1}$

We note in passing that it may be useful to separate collecting and winnowing from parching as distinct activities for which basketry may have served as a crucial piece of technology. A means of mass collecting small seeds is absolutely essential, whereas parching might be seen as a secondary step, and in some parts of the world, not preformed at all (e.g., Australia, [Cane 1989; Gould 1969]). In western North America, the ethnographic literature documents basketry's close association with seed processing. In both California and the Great Basin, twined and coiled basketweaving techniques were used to produce seed storage jars, hoppers, seed beaters, and trays of various sizes for winnowing, sifting, and parching (e.g., Aschmann 1952; Elsasser 1978; Fowler and Dawson 1986; see also their references). Elsewhere in North America, a heated flat stone or basket tray was typically employed to parch seeds or maize (Driver and Massey 1957). Where pottery is used by itself or interchangeably with a basket for parching, as in the Southwest, the ceramic vessel is thought to have filled the role occupied formerly by a basket (Driver and Massey 1957:245-247). In Australia, basketry does not appear to be a component of seed processing technology (Cane 1989; Gould 1969; Roth 1901). Instead, large, slightly concave wooden dishes are used for winnowing and as a receptacle for grinding, but parching does not appear to be practiced.

Archaeologically, coiled parching trays are abundant in the large basketry assemblages recovered from the Great Basin (e.g., Adovasio 1970a, 1970b, 1986; Heizer and Krieger 1956; Loud and 
Harrington 1929; Rudy 1957), excepting the Northern Great Basin sub-area where twined basketry was preferred for seed processing (Adovasio 1986; Cressman 1942). Complementary data from prehistoric eastern North America on winnowing or parching trays of any type are equivocal (Gremillion 2004:225). There is evidence from the Southwest and Mexico, however, that coiled parching trays were as equally abundant and have antiquity comparable to that of the Great Basin (Adovasio 1974, 1980; Fowler 1996; Hyland et al. 2003:343-359; Lindsay et al. 1968; McGregor 1992; Morris and Burgh 1941; Taylor 1966). ${ }^{2}$

In a series of publications, Adovasio (1970a, 1974, 1980, 1986) suggests that coiled basketry technology was innovated independently in the eastern Great Basin by the ninth millennium before present as a specialized food preparation technique among Archaic foragers. This was done specifically for parching, "a use for which twining is ill-suited," presumably because coiling is sturdier and more evenly distributes heat (Adovasio 1970a:22, 1974:116, 1980:357). Based on technical similarities, early coiling from the Colorado Plateau has been viewed as derivative of Great Basin prototypes. In coiled basketry a passive horizontal element or set of elements (the foundation) is sewn by an active vertical element (the stitches) (see Figure 2 ). The principal structural unit of the coiled basket is its coil, which emanates from the center of the basket in a continuous spiral. Coiled basketry does not appear in the Danger Cave deposits until DIII, well after the switch to small seed consumption. Coiled basketry may have been known at the site as early as ca. 8800-7300 B.P. given the potential age range for the earliest coiled basketry specimens from Strata 3 and 4 at neighboring Hogup Cave (Figure 1) (Adovasio 1970b; Aikens 1970:Table 2), but this remains to be demonstrated by direct dating.

Twined basketry has considerable antiquity in the northern and western Great Basin, but these early objects do not appear related to intensive seed processing, consisting instead of sandals, mats, burial wrappings, and flexible containers of various shapes and sizes (Connolly and Barker 2004; Fowler et al. 2000; Hattori and Fowler 2005). The implication is that twined basketry production existed well before the transition to small seed exploitation and that the means of producing con- tainers for collecting and processing seeds was extant before the need was present. Adovasio's hypothesis for the origin of coiled basketry assumes that coiled wares are functionally superior to twined varieties for parching small seeds and that the technology developed initially in the eastern Great Basin and then rapidly diffused southward. Based on the available data, however, it seems premature to exclude an origin in northern Mexico (Jolie and Hattori 2005; see also Adovasio 1980:357). Ignoring for now the debate over the precise region (or regions) of origin of coiling, there is ample reason to doubt that coiling is superior over twining for seed processing and that coiling was invented for seed processing. Coiling appears to be sufficient but not necessary for a small seed adaptation and, as with twining, may have been invented for reasons that have nothing to do with seed processing, but that proved ideal for that purpose once the need arose. When and what role coiled basketry technology played in the transition to intensive small seed processing are issues that we will return to below.

With small seed use now known to be no older than 8700 B.P. in the eastern Great Basin, there may no longer be a temporal priority for this adaptation in that region compared to the Colorado Plateau. The archetypal residues of generalist foragers, consisting of low-rank small seeds of diverse plants and the grinding slabs and manos for their processing, have been recovered from numerous shelters of the Colorado Plateau. Dust Devil and Walters caves, located in heart of the Canyonlands Section of the plateau (see Figure 1), have produced the earliest reliable dates (those not subject to age overestimation) putatively associated with a small seed adaptation. At both sites, yucca leaves have radiocarbon ages between $8800-8900$ B.P. (Ambler 1996:Table 1; Jennings 1980:Table 3), with the Walters Cave date on an open-twined sandal (see Geib 1996a: Note 2), the favored footwear of early Archaic foragers for this portion of the Colorado Plateau (Geib 2000). The evidence for small seed consumption at or before 8800 B.P. at either site is conjectural-a hypothesis to be tested-and may not be any more valid than the original claim for 9000-10,000 B.P. seed use at Danger Cave and, by implication, the eastern Great Basin generally. The earliest direct dates on human feces containing small seeds for the Colorado Plateau are after 8000 
B.P. (Dust Devil Cave at $7630 \pm 120$ B.P. and Old Man Cave at $7680 \pm 90$ B.P.; Geib 1996b:Table 5), so the beginning of small seed consumption remains to be demonstrated.

One obvious line of evidence to address this issue is by directly dating human feces containing small seeds, the approach taken by Rhode et al. (2006). Another critical line of evidence concerns the technology essential to the economic exploitation of this resource. Grinding stones provide just one data set in this regard, but such tools are difficult to directly date and they could also have functions other than those commonly assumed (e.g., pigment grinding or hide preparation) (Adams 1999), though function can be demonstrated through starch grain analyses (Pearsall 2000; Piperno and Holst 1998; Rowe 2001a). ${ }^{3}$ Basketry samples are extremely useful because they can be directly dated by the AMS technique and because they contain functional clues in their form, wear patterns, and potential residues. We are exploring each of these avenues of inquiry, but for now we are concerned with basketry, specifically, the recently discovered whole basket from Cowboy Cave. This is an admittedly modest beginning, but every construction starts with a first stone or, given our subject matter, the initial spiral of a foundation rod.

\section{The Cowboy Cave Basket}

\section{The Site}

Cowboy Cave is a large and deep natural shelter formed within Navajo Sandstone in a tributary drainage (Horseshoe Canyon) of the Green River within southeast Utah (see Figure 1). The cave measures about $12 \mathrm{~m}$ wide at its mouth and $33 \mathrm{~m}$ deep. Immediately adjacent is Walters Cave, which measures about $11 \mathrm{~m}$ wide at its mouth but just $15 \mathrm{~m}$ deep. The most habitable portion of Cowboy Cave (the front lighted part), an area of about $138 \mathrm{~m}^{2}$, was completely excavated to or below a culturally sterile layer of Pleistocene herbivore dung by a University of Utah archaeological field school in 1975. Excavations revealed 1-2 m of complexly stratified deposits from almost 7,000 years of occupation. For this reason, the site has figured prominently in many reconstructions of the Archaic period in the Southwest (Berry and Berry 1986;
Geib 1996b; Huckell 1996; Schroedl 1976). Jennings (1980:9-26) grouped the numerous individual strata of the site into four cultural units thought to represent coherent intervals of occupation separated by periods of site abandonment. A subsequent evaluation of the evidence supports the overall idea of several sequential intervals of use and abandonment, but refines the chronology and reassigns most of the intervening hiatus layers (Schroedl and Coulam 1994). For a site that has assumed so much significance with regard to our understanding of early prehistory on the northern Colorado Plateau, there are relatively few radiocarbon assays, especially for the earliest portion of site occupancy.

\section{Basket Discovery}

The senior author visited Cowboy Cave in January of 2006 while camping in the general area. Inside the cave, just beyond the portion obviously excavated by the University of Utah field school, was a large looter hole. Along one edge of this cut, near the surface, occurred what appeared to be part or all of a small coiled basket inverted on its rim (Figure 3). Although occurring within apparent intact cave strata (i.e., not looter disturbed), it did not seem noteworthy given its occurrence high in the deposits of Cowboy Cave, merely part of the very last occupation of the site sometime during the first millennium A.D. Fearing unlawful removal of the basket or destruction by an errant cow, the senior author notified Craig Harmon, District Archaeologist for the Bureau of Land Management (BLM), who recovered the artifact several weeks later. Shortly thereafter the basket was transferred to the Utah Museum of Natural History (UMNH) at the University of Utah in Salt Lake City where we analyzed and photographed it.

\section{Basket Description}

The basket was analyzed according to the methods and procedures outlined by Adovasio (1977) and we follow his terminology. Because this basket represents a structural type different from the other basketry specimens from Cowboy and Walters caves that Hewitt (1980) described, we here assign this basket a nonsequential subclass number, 13, to avoid contradictions with her report.

The exceptionally well-preserved basket is a small, rigid open-mouthed bowl $10 \mathrm{~cm}$ in diame- 


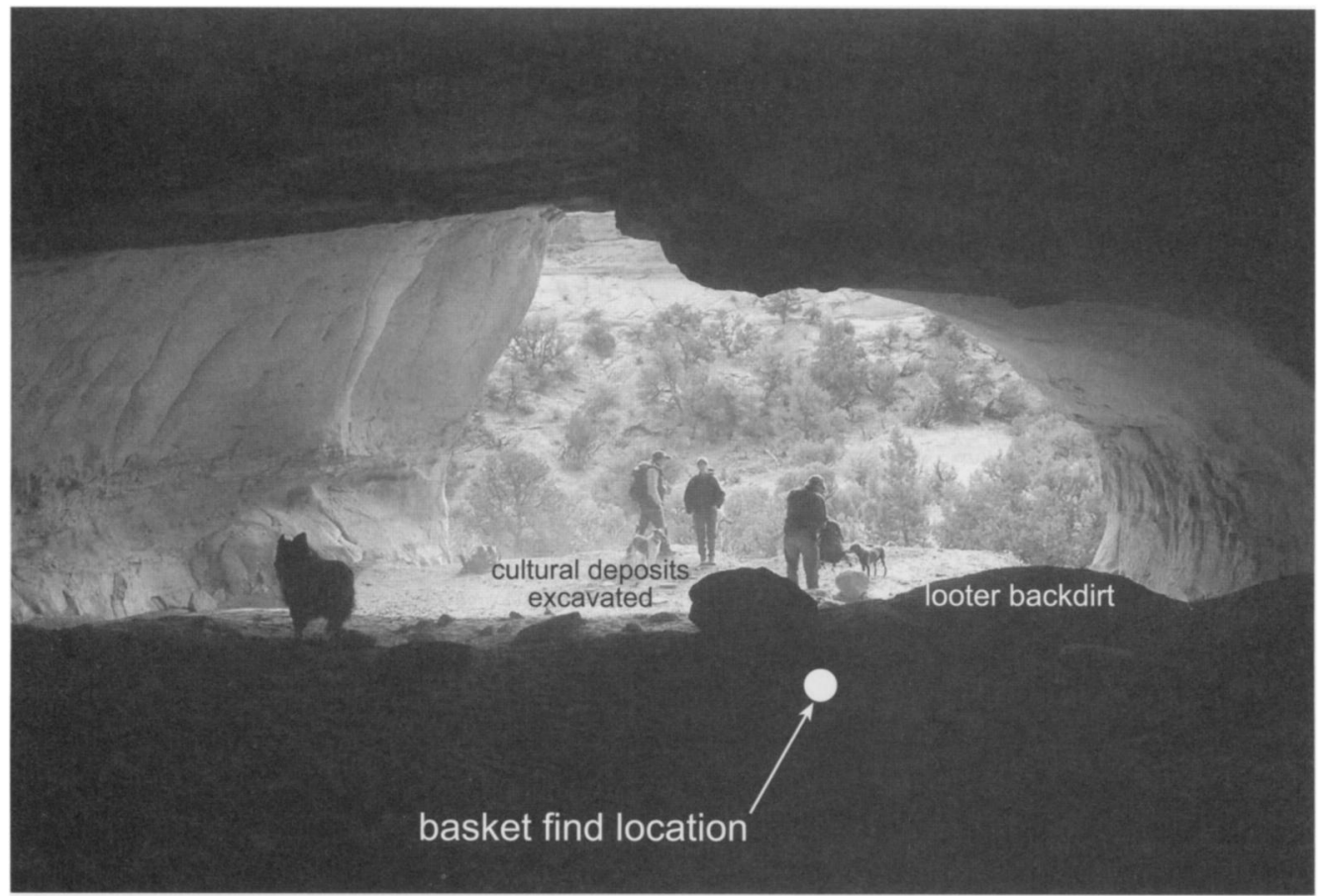

Figure 3. View out the mouth of Cowboy Cave from the back showing the location of discovery.

ter and $4.3 \mathrm{~cm}$ high (Table 1, Figures 4 and 5). It has a volume of $150 \mathrm{ml}$ (measured with domesticated mustard seed), or about two thirds of a standard measuring cup. The basket is undecorated, unpitched, unmended, permeable, and exhibits little to no use wear; its precise function is unknown. There is a small, apparently post-depositional depression on one side of its base, amorphous stains from packrat urine occur on both surfaces, and rat feces and sandy matrix adhere to one portion of the base.

The basket was made by sewing a single whole rod of an unidentified woody plant (with its cortex intact), possibly a member of the Rosaceae family, with non-interlocking stitches of a different peeled shoot material. The stitches consistently pierce the foundation rod. The basket has accidentally split stitches on both surfaces and there are gaps between the stitches that expose the foundation. The stitches appear to have a slightly perpendicular arrangement, but it is unclear if this was intentional or merely a by-product of sewing non-interlocking stitches in such small circuits. The work surface is convex (exterior) and the work direction (stitch slant) is left to right (rightward). The start is of the continuous coil (normal) variety and very tight, with no central aperture. It has a simple self rim finish and abrupt termination. The rim coil is slightly larger in diameter than preceding coils $($ range $=6.4-8.1 \mathrm{~mm} ;$ mean $=7.3 \mathrm{~mm})$, and the rim's stitches are larger as well (range $=3.7-4.3$ $\mathrm{mm}$; mean $=4.0 \mathrm{~mm}$ ). A single probable foundation splice is located on the final coil some $20.5 \mathrm{~cm}$ before the rim termination. Apparently, a young shoot of uneven width (tapered) was folded on itself $180^{\circ}$ over about $6.5 \mathrm{~cm}$ and then abutted against the end of the exhausted rod. Stitch splice fag ends are clipped short, close to the basket's surface, while moving ends are bound under the exhausted thread's final stitch or, in some loci, clipped short immediately next to the exhausted thread's final stitch.

\section{Basket Dating}

Using year end BLM money, Craig Harmon authorized submission of a sample from the basket for AMS radiocarbon dating. Kathy Kankainen, curator of collections at the UMNH, obtained the sample by snipping off the last stitch piercing the rim coil (Figure 5). Given the essentially perfect condition of the basket, this was the most accessible and easily removed part with the least impact. It 
Table 1. Metric and Analytic Data for Small, Complete Coiled Basket from Cowboy Cave (UMNH A.2006.16/AR 59068).

\begin{tabular}{ll}
\hline Attributes & Measurements \\
\hline Diam. of Coil (range in mm) & $5.6-6.5$ \\
Mean Diam. of Coil (mm) & 6.0 \\
Coils Per cm (range) & 2.5 \\
Mean Coils Per cm & 2.5 \\
Work Surface & Convex \\
Work Direction & L-R \\
Stitch Width (range in mm) & $2.5-3.2$ \\
Mean Stitch Width (mm) & 2.8 \\
Stitches Per cm (range) & $2-2.5$ \\
Mean Stitches Per cm & 2.1 \\
Stitch Gap (range in mm) & $1.7-2.6$ \\
Mean Stitch Gap (mm) & 2.2 \\
Split Stitch Frequency, Work Surface & $9 \%$ \\
Split Stitch Frequency, Non-work Surface & $20 \%$ \\
\hline
\end{tabular}

Basket is Subclass 13: close coiling, one rod foundation, non-interlocking stitch

should be noted that this portion of the basket was not stained by packrat urine, the effects of which, if present and not removed in pretreatment, would result in a younger than true age. The small stitch segment was submitted to Beta Analytic; consisting of woody material, the sample provided plenty of carbon. The conventional radiocarbon age for this sample is $7960 \pm 50$ B.P. (-22.6\%o, Beta218759). This assay falls during a relatively flat portion of the calibration curve such that the two sigma range is moderately wide at $7060-6670 \mathrm{cal}$. B.C. (9010-8620 cal. B.P.; calibration according to Stu- iver et al. [1998]). The significance of this date with regard to the early history of site use is considered first, followed by an examination of internal and external comparisons, and then a discussion of the development of small seed exploitation and the role that coiled and twined basketry played.

\section{Cave History}

As is true for many sites excavated prior to about the mid 1980s, relatively few radiocarbon dates are available for Cowboy Cave, especially given the

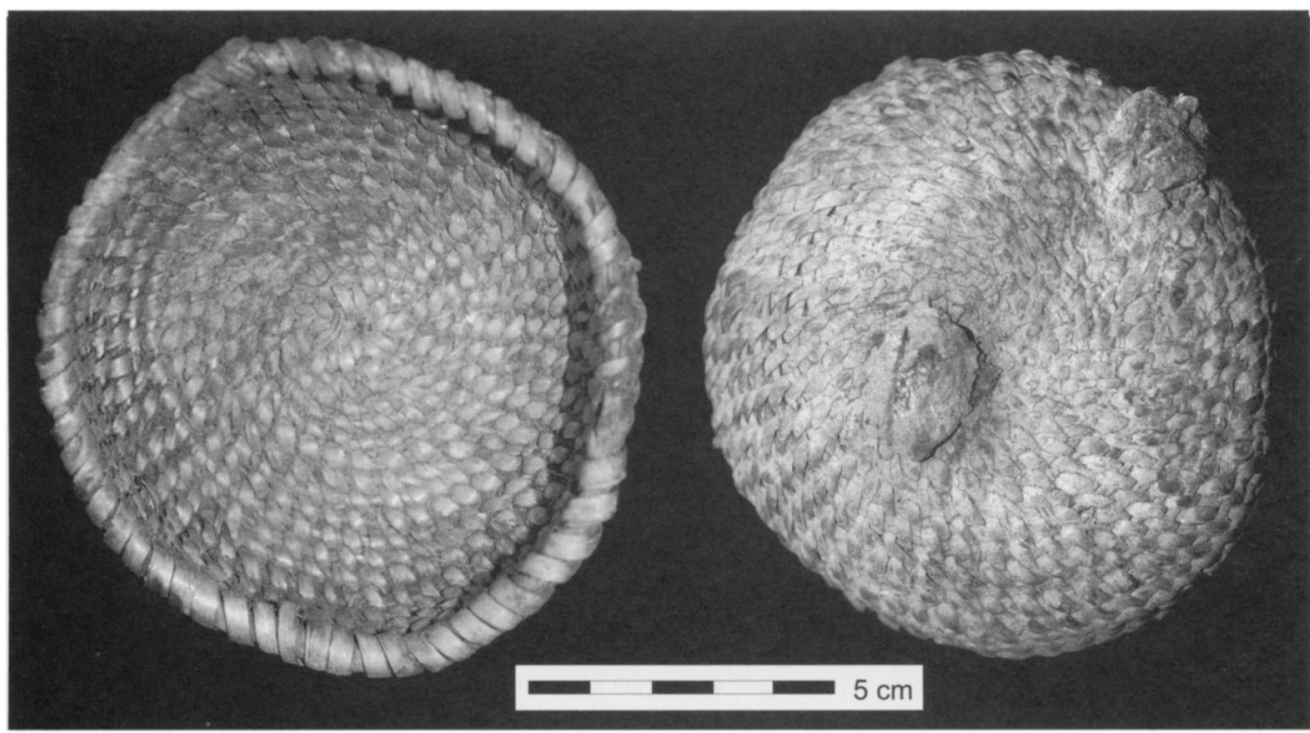

Figure 4. Interior and exterior views of the basket discovered at Cowboy Cave (UMNH A.2006.16/AR59068). Photos by Edward A. Jolie, courtesy of the Utah Museum of Natural History. 


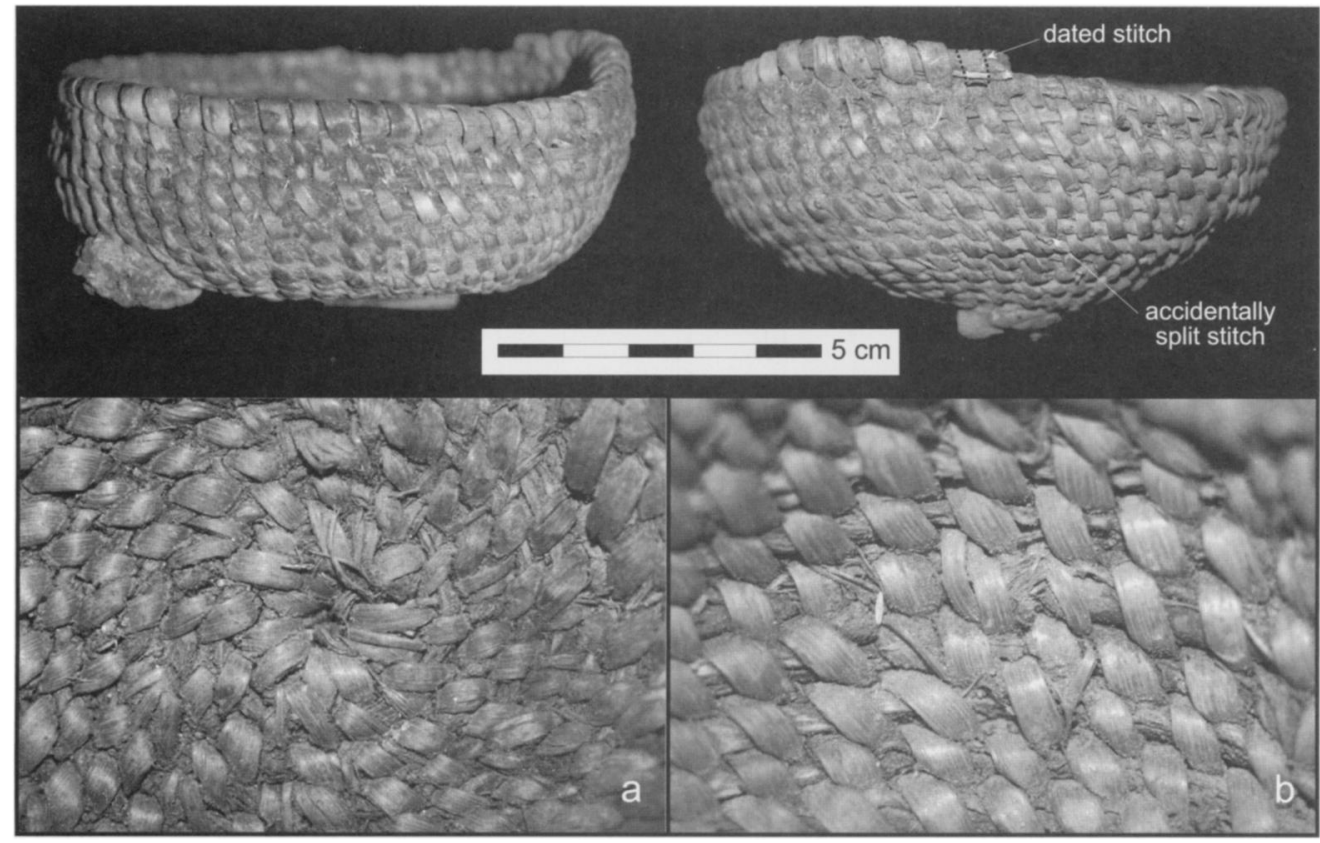

Figure 5. Side views of the Cowboy Cave basket, along with (a) close-up images showing the method of starting and (b) a stitch moving end bound under an exhausted thread's final wrap. Photos by Edward A. Jolie, courtesy of the Utah Museum of Natural History.

complexity of its stratification and several thousands of years of site use. The current summary of dates for the site is presented by Schroedl and Coulam (1994:Table 2), which includes a few dates obtained on sandals well after publication of the site report (Geib 1996a), as well as clarification of the dates on the infamous corn cache, the reporting of which has created considerable confusion (see Geib 1996b:55-56). Given the relative scarcity of dates for a site of this nature, particularly with regards to the significance it holds for our understanding of regional prehistory, all dating information is valuable. Figure 6 shows the distribution of previous radiocarbon dates in relation to stratigraphy for Cowboy Cave, along with placement of the new basket date. A previous date on an opentwined sandal from the adjoining Walters Cave is also plotted since it may mark the beginning of human use of both shelters.

The recently obtained basket date is currently the second earliest assay for Cowboy Cave, with an older date of $8275 \pm 80$ B.P. on charcoal. Given the probable burning of old wood and thus the potential unreliability of the charcoal assay, the basket date is the earliest one from the site that is unlikely to overestimate age. Next in line is an assay of $6675 \pm 75$ B.P. on a yucca sandal, which is some 1,600 radiocarbon years later. This serves to highlight that the dating of the early Archaic layers of Cowboy Cave need attention; there are too few assays to provide a solid description for when the site was used. For the earliest cultural deposition at the site, Strata IIb and IIIa, there is a single charcoal assay. For the somewhat later deposits (Strata IIIb-IVb) there are six assays, but three of these are clustered at the very end of early Archaic use (IIIi-IVb), and only one of the other three is not subject to age overestimation. Unit III deposits are a thick and complicated accumulation that account for the majority of deposition in the cave during the early Archaic.

Schroedl and Coulam (1994:21) place the earliest component at Cowboy Cave as ranging in age from roughly 7430-7100 cal. B.C. and represented by Stratum IIb. Because the immediately adjacent Walters Cave has an open-twined sandal dated at $8875 \pm 125$ B.P. (ca. $8030-7710$ cal. B.C.), earlier use of Cowboy Cave is probable. The basket date reported here occurs after Schroedl and Coulam's projected temporal span for the deposition of Stratum IIb but prior to when Stratum IIIb began accumulate. They argue for a dramatic shift in cave use, 


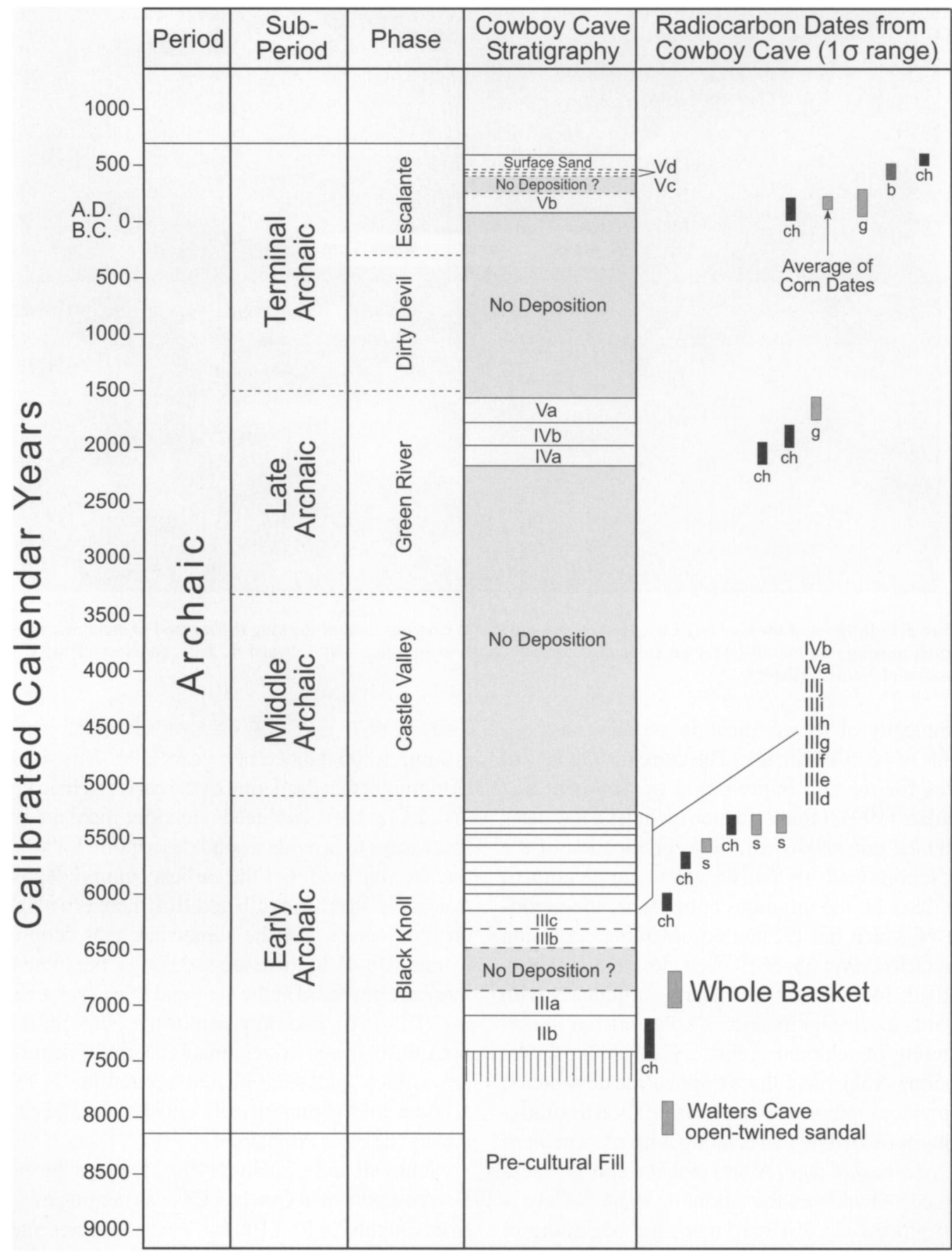

Figure 6. Distribution of radiocarbon dates in relation to the stratigraphy for Cowboy Cave. The date on an open-twined sandal from the adjoining Walters Cave is also included. Note that stratum thickness on this graph bears no relation to actual depositional thickness. Below each radiocarbon date small letters designate the item assayed: ch, charcoal; s, sandal (yucca); g, grass, and b, bark. Figure redrawn and modified from Schroedl and Coulam (1994:Figure 3). 
from a short-term summer camp to a winter encampment (residential base), during which structures were erected in the cave (Schroedl and Coulam (1994:22). They suggest that this occurred sometime after $7100 \mathrm{cal}$. B.C. but before $6000 \mathrm{cal}$. B.C., which means that the basket comes from the unknown interval during which Strata IIIa through IIIc were deposited; it is even possible that the basket relates to the interval that Stratum IIb accumulated.

Stratum IIb appears to represent an Archaic adaptation because the human feces from this layer contain small seeds (Hogan 1980) and because both manos and metates were recovered (Dodge 1980). The total number of human feces retrieved from Straum IIb is unreported, but Hogan (1980:Table 2) lists 12 specimens as being analyzed from this layer and all contain small seeds, with nine of these containing high frequencies. Despite this evidence, only a single tiny piece of basketry is reported from Stratum IIb (Hewitt 1980:Table 12), which recent dating indicates is intrusive, and there is no other basketry until Stratum IIIg, after 6000 cal. B.C. $^{4}$ The question remains: If small seeds were being exploited, was this done without coiled basketry, or is it just a preservation problem? An unlikely alternative, but one needing investigation, is that the Stratum IIb evidence for seed consumption is illusory, a product of unrecognized stratum boundaries during excavation, with seed use actually postdating the accumulation of this layer. Direct dating of the Cowboy Cave feces would quickly test this possibility, a plan for which is currently in the works. What is clear from the current basket date is that the basic technology for making the necessary containers for efficient small seed exploitation was present at Cowboy Cave between 7000 and $6700 \mathrm{cal}$. B.C.

\section{Internal and External Comparisons}

In her description of the worked fiber artifacts from Cowboy and Walters caves, Hewitt (1980) identifies 12 different structural techniques employed in 74 individual fragments of coiled basketry (Table 2). Twined basketry is conspicuously absent from the entire Cowboy and Walters caves assemblages, though the technology was certainly available to the occupants of both sites because they employed open twining to produce sandals (Hewitt 1980).
Three coiled basket fragments (Subclasses 2, 3 and 6) are from Units 4 and 5 at Walters Cave (Hewitt 1980:Table 14) and should significantly postdate the basket reported here. At Cowboy Cave, coiled basketry with one rod and welt foundations (Subclasses 3 and 4) are the earliest and most popular in the assemblage, followed by those that contain one rod and bundle foundations (Subclasses 5 and 6). Both foundation types include interlocking and non-interlocking stitch varieties that enjoy continuous use throughout the Cowboy Cave sequence. Only a single specimen of one rod and welt foundation, split stitch close coiling (Subclass 4) from Stratum IIb, is potentially older than the basket described here. It is assigned a stratigraphic age of 7430-7100 cal. B.C., but recent direct dating of this specimen indicates that it is younger and evidently intrusive from Unit III (see Note 4).

The present discovery represents a previously unknown structural type from Cowboy Caveclose coiling with a one rod foundation and noninterlocking stitches-and is also the first complete basket from the site. The next oldest basket fragments derive from Strata IIIg-IIIi thought to postdate $6000 \mathrm{cal}$. B.C. These specimens document the continued use of Subclass 4 coiling and also an increase in technological diversity through time (the addition of Subclasses 2, 3, 5, 7 and 11, but this needs to be confirmed by reanalysis in conjunction with new dating results). The apparent trend of foundation type elaboration through time, beginning with single element foundation types to which multiple element varieties are later added, has been documented at several sites throughout western North America and Mexico (Adovasio 1970a, 1974, 1980, 1986). Few metric data or observations on specific construction attributes such as raw material, rim finish, and starting method are available in the published literature to permit direct comparisons between this basket and other early fragments. Published photos do, however, suggest a basic similarity in the employment of simple self rim finishes and continuous coil starts. If the left to right (rightward) work direction of this one rod foundation basket is equivalent to Hewitt's "left slant," then it appears that although both directions are employed at Cowboy Cave, a right to left (leftward) work direction is slightly preferred. The whole basket compares favorably with some of the more finely stitched baskets in the collection that 
Table 2. Distribution of coiled basketry Subclasses 1-12 at Cowboy Cave by stratum from Hewitt (1980:Table 12).

\begin{tabular}{|c|c|c|c|c|c|c|c|c|c|c|c|c|c|c|}
\hline \multirow[b]{2}{*}{ Subclass } & \multirow{2}{*}{$\frac{\mathrm{II}}{\mathrm{b}}$} & \multicolumn{4}{|c|}{ III } & \multicolumn{2}{|c|}{ IV } & \multicolumn{4}{|c|}{ V } & \multirow[b]{2}{*}{ Surface } & \multirow[b]{2}{*}{ No Prov. } & \multirow[b]{2}{*}{ Total } \\
\hline & & $a-c ?$ & $\mathrm{~g}$ & $\mathrm{~h}$ & $\mathrm{i}$ & $\mathrm{c}$ & $\mathrm{d}$ & $\mathrm{a}$ & b & $\mathrm{c}$ & d & & & \\
\hline $\begin{array}{l}\text { 1: One Rod, } \\
\text { Intricate Stitch }\end{array}$ & & & & & & 2 & 1 & 2 & 1 & & & & 2 & 8 \\
\hline $\begin{array}{l}\text { 2: One Rod, } \\
\text { Interlocking Stitch }\end{array}$ & & & & & 1 & 1 & & & 1 & & & & & 3 \\
\hline $\begin{array}{l}\text { 3: One Rod and Welt, } \\
\text { Non-interlocking Stitch }\end{array}$ & & & 1 & & 1 & 1 & 3 & 1 & 2 & 1 & 1 & & 3 & 14 \\
\hline $\begin{array}{l}\text { 4: One Rod and Welt, } \\
\text { Split Stitch }\end{array}$ & 1 & & & 1 & & 1 & & 1 & 2 & 2 & 1 & & 2 & 11 \\
\hline $\begin{array}{l}\text { 5: One Rod and Bundle, } \\
\text { Non-interlocking Stitch }\end{array}$ & & & & 3 & & 2 & 1 & 1 & 5 & & 1 & & 1 & 14 \\
\hline $\begin{array}{l}\text { 6: One Rod and Bundle, } \\
\text { Split Stitch }\end{array}$ & & & & & & & & 1 & 5 & 1 & & 1 & & 8 \\
\hline $\begin{array}{l}\text { 7: Two Rod Stacked, } \\
\text { Interlocking Stitch }\end{array}$ & & & & & 1 & & & & & & & & & 1 \\
\hline $\begin{array}{l}\text { 8: Two Rod Stacked, } \\
\text { Split Stitch }\end{array}$ & & & & & & 2 & 1 & & 1 & & & & 1 & 5 \\
\hline $\begin{array}{l}\text { 9: Two Rod and Welt, } \\
\text { Interlocking Stitch }\end{array}$ & & & & & & & & & & 1 & & & & 1 \\
\hline $\begin{array}{l}\text { 10: Two Rod and Bundle, } \\
\text { Non-interlocking Stitch }\end{array}$ & & & & & & & & & 1 & 1 & & & & 2 \\
\hline $\begin{array}{l}\text { 11: Bundle, } \\
\text { Non-interlocking Stitch }\end{array}$ & & & 1 & & & & & & & & 1 & & & 2 \\
\hline $\begin{array}{l}\text { 12: Splint, } \\
\text { Non-interlocking Stitch }\end{array}$ & & & & & & 1 & & & & & & & & 1 \\
\hline $\begin{array}{l}\text { 13: One Rod, } \\
\text { Non-interlocking Stitch }\end{array}$ & & 1 & & & & & & & & & & & & 1 \\
\hline Unidentified & & & & & & & & 1 & & & & & & 1 \\
\hline Total & 1 & 1 & 2 & 4 & 3 & 10 & 6 & 7 & 18 & 6 & 4 & 1 & 9 & 72 \\
\hline
\end{tabular}

Excepting Subclass 1, which is open coiling, all are close coiling types. Subclass 13, in bold, constitutes the new technological type described in this paper. The three fragments from Walters Cave are not included here.

exhibit between two to four stitches per $\mathrm{cm}$. Regarding form and function, Hewitt (1980:53) reports that 11 basket fragments exhibit charring and might suggest use in parching, but she does not state if any of them are from early strata (five of Subclass 3 and six of Subclass 4). From our examination of the basketry at the site, it is clear that a few parching tray fragments came from the early Archaic strata, including a specimen nearly as old as the one considered here (Figure 7).

Moving beyond Cowboy Cave, we find that there are roughly contemporaneous examples of coiled basketry reported from a handful of sites in the eastern Great Basin and on the Colorado Plateau that share broad similarity in technological features with the current discovery. At Hogup Cave, Adovasio (1970b) reports two examples of half-rod and welt foundation coiling sewn with interlocking stitches from Stratum 3. Stratum 4 yielded three more examples of this type, as well as two frag- ments of half rod foundation coiling sewn with interlocking stitches, one piece of half rod and bundle stacked foundation coiling sewn with noninterlocking stitches, and one piece of two rod and welt bunched foundation coiling sewn with split stitches. Several of these fragments appear to have come from parching trays. Radiocarbon determinations bracketing Strata 3 and 4 indicate an age range between about $8800-7300$ B.P. (Aikens 1970:Table 2). Recently, Jolie (2004:180) acquired a direct AMS determination of $6440 \pm 40$ B.P. on a fragment of half rod and bundle stacked foundation coiling sewn with non-interlocking stitches. This specimen, recovered from lower Stratum 8 (dated stratigraphically to between roughly 6190-2600 B.P.), was part of a steep-sided container and exhibits feather decoration in the form of chevrons. The AMS age of this specimen underscores the significant cultural and natural mixing experienced by most cave and rockshelter deposits. 


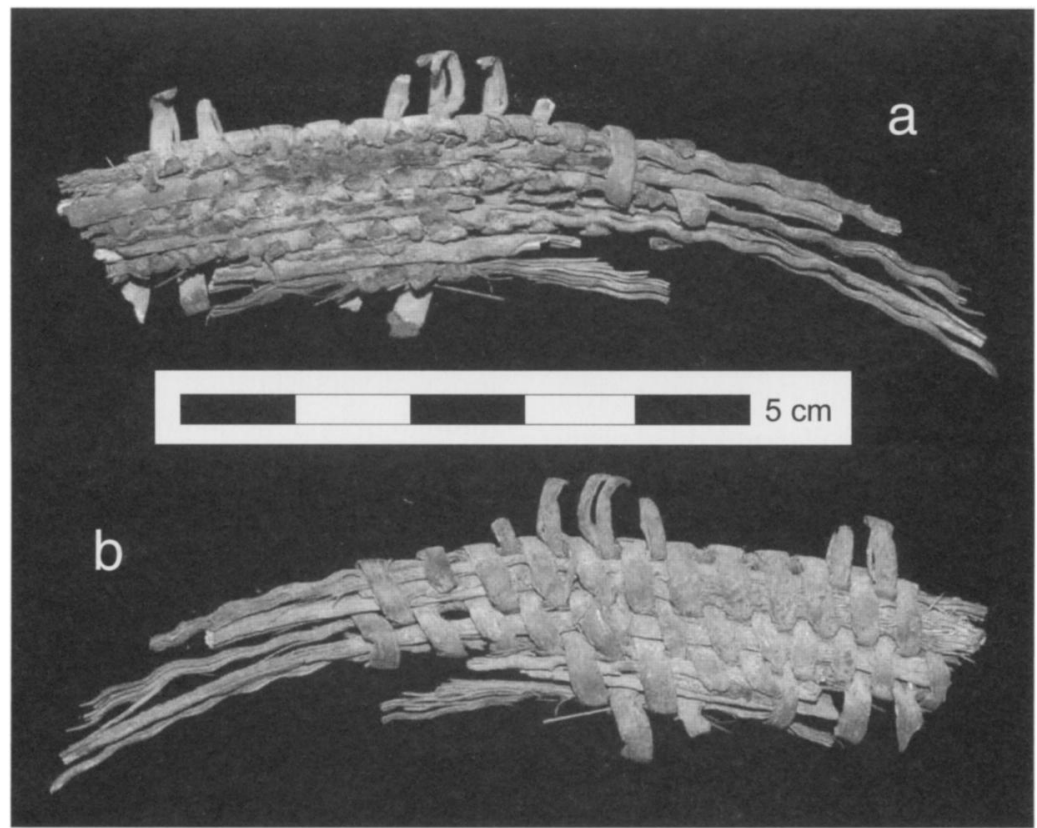

Figure 7. Example of a coiled parching tray fragment (FS 1403.6) from the early Archaic deposits of Cowboy Cave. This fragment has a half-rod and welt stacked foundation and is sewn with non-interlocking stitches with a work direction, as indicated by stitch slant, from the left to the right (rightward): (a) concave face or basket interior; (b) convex face or exterior side. Note the suite of technical and use wear characteristics, such as close coiled construction, heavy charring and missing stitches on only the concave face, that are typical of parching trays. Photos by Edward A. Jolie, courtesy of the Utah Museum of Natural History.

Graf (2007) reports a direct AMS date of $7190 \pm$ 50 B.P. on a coiled basket fragment from Bonneville Estates Rockshelter, which is located in eastern Nevada about $30 \mathrm{~km}$ southwest of Danger Cave. Preliminary analyses of this and other fragments from the same layer document the use of single element (including whole and half rod) foundations and interlocking or possible intentionally split stitches to make parching trays (Jolie and Burgett 2002). On the Colorado Plateau, Lindsay et al. (1968) report two examples of coiled basketry from the "Desha Complex" levels at Sand Dune Cave, dated between 7800-7200 B.P. Both appear to be fragments of parching trays, one with a one rod foundation sewn with interlocking stitches and the other exhibiting a two rod and bundle foundation sewn with non-interlocking stitches (possibly an intrusive Basketmaker II artifact). The Desha Complex layers of the nearby Dust Devil Cave (Ambler 1996) also produced two examples of coiled basketry, both with one rod foundations sewn with interlocking stitches. One of these is reported by Lindsay et al. (1968), while the other specimen was recovered by J. Richard Ambler dur- ing his 1970 excavations, but is not yet published.

Turning to points further south, early coiled basketry has been reported from several sites in the Trans-Pecos region of Texas and adjacent northern Mexico. From Hinds Cave in Val Verde County, Texas, open and close coiled bundle foundation wares with interlocking stitches dominate strata dating between 7550-6050 cal. B.C. (Andrews and Adovasio 1980:331). Several of these fragments may have been parching trays or bowls for preparing food. However, one specimen is identified as a scarifier (tattooing needle) with a close coiled bundle foundation basket handle. Taylor (1966; see also Adovasio 2003) reports early coiled basketry of unknown form and function exhibiting whole and half rod foundations sewn with split and interlocking stitches from Frightful and Fat Burro caves in central Coahuila, Mexico, that are dated between $7500-4000$ cal. B.C. A handful of coiled specimens recovered from caves in Tamaulipas, Mexico (by MacNeish [1958]) may be broadly contemporaneous with the Coahuila finds, but these Tamaulipas examples remain poorly dated and described (Adovasio 1980:348; Hyland et al. 
2003:348). Adovasio's $(1974,1980)$ research on both collections indicates evidence for their use as parching trays. In central Mexico's Tehuacan Valley, MacNeish et al. (1967) document early bundle foundation coiling with non-interlocking stitches in the form of "dish-pan" shaped baskets that date between $6500-4800 \mathrm{cal}$. B.C. Given the revision of the age of early maize from this valley (Long et al. 1989), the associated dates for the basketry should be viewed with caution. Further afield, King $(1979,1986)$ describes a small close coiled plaque with a bundle foundation and interlocking stitches from Guilá Naquitz in Oaxaca that dates between 6910-6670 cal. B.C. This basket appears to be a finished miniature plaque, $5.5 \mathrm{~cm}$ in diameter, of uncertain function.

Though the evidence for early coiling is still quite limited, the earliest examples of this technique come from a corridor extending from northern Utah south into Mexico (Adovasio 1980). The majority of this basketry is characterized by single-element foundation types (whole or half rods) much like the one rod foundation example from Cowboy Cave under discussion, and an apparent preference for interlocking stitches (subsuming split stitches, which are technically interlocking), though noninterlocking specimens do occur. The complete Cowboy Cave basket is one such example. Singleelement foundation types, much like those summarized here, persist in varying frequencies up to the historic period in the immediate study area and throughout much of western North America (e.g., Adovasio 1986; Elsasser 1978; Fowler and Dawson 1986; Mason 1904; Morris and Burgh 1941). This pattern holds in Mexico except for the clear preference for grass bundle foundations at a very early date. Many, but notably not all, of the early coiled basket fragments appear heavily charred on one face, which suggests use as parching trays. It deserves mentioning that the extensive charring or carbonization of some fragments may have favored their preservation over other types of baskets, although we have no clear evidence of such a bias. The only complete baskets of great antiquity that have yet been reported are the Hinds Cave scarifier and the examples from Cowboy Cave and Guilá Naquitz, so we are left with charring and residues as the best indicators of function for fragmentary specimens.

\section{Intensive Small Seed Processing and the Development of Coiled Basketry}

Our current understanding of prehistoric basketry illustrates that coiling represents one of the last major developments in North American basketweaving. It is clearly preceded by complex twined and plaited basketry industries and, once developed, coiled basketry increases in quantity, technical sophistication, and economic importance through time (Jolie and Hattori 2005). New radiocarbon dates and reanalyses of existing collections are clarifying our understanding of coiled basketry's spread throughout North America in particular places at particular times, but these new data also serve to underscore the complexity of the technology's origins (Jolie 2004, 2006). It remains that we know very little about the timing of its development and what provoked it. Here we return to these issues and offer some ideas about when and why coiled basketry technology developed in light of the recent Cowboy Cave find.

Adovasio's hypothesis for the origin of coiled basketry assumes that coiled wares are functionally superior to twined varieties for parching small seeds and that the technology developed initially in the eastern Great Basin and then rapidly diffused southward. However, based on the available data, it seems premature to exclude an origin in northern Mexico (Jolie and Hattori 2005; see also Adovasio 1980:357). Regardless, there is ample reason to doubt that coiling is superior over twining for seed processing or that coiling was invented for seed processing. Coiling appears to be sufficient but not necessary for a small seed adaptation (witness the Australian aborigines who use wooden trays) and, as with twining, may have been invented for reasons that have nothing to do with seed processing, but that proved ideal for that purpose once the need arose.

The first claim is based on the historically documented hunter gatherers that exclusively employed a suite of twined basket forms including twined winnowing trays, parching trays, and seed beaters. Prime examples are the Northern Paiute Numic language-speakers of western Nevada (also the Southern Paiute of the Colorado Plateau) and the Klamath Penutian language-speakers of southcentral Oregon. Both groups have basketry industries dominated by twining and they manufacture 
very functional seed processing paraphernalia using this technique. Prior to the Numic Expansion (Bettinger and Baumhoff 1982; Madsen and Rhode 1994), coiling was abundant in western Nevada, but was rare in the northern Great Basin (Connolly 2006), indicating the possibility that some of the northern examples may have been imports (Jolie 2004). Archaeological and ethnohistoric data show that coiled basketry was a recent introduction among the historic Northern Paiute (within the last several hundred years), and that it had replaced only a few older twined forms during this period (Adovasio 1986; Fowler and Dawson 1986). Coiling among the Klamath, by comparison, has always been scarce, and was probably the product of exchange (e.g., Spier 1930). Further, there is considerable evidence for long-term cultural continuity in the region. Twined basketry closely resembling historic Klamath wares in many construction features goes back in excess of 10,000 years; at no point did coiled basketry ever constitute a significant percentage of the basketweaving repertoire (Adovasio 1986; Conn and Schlick 1998; Connolly and Barker 2004; Cressman 1942, 1986). In sum, both groups are heirs to twined-basketry traditions of considerable antiquity and for whom coiling is either a recent introduction or, as with the Klamath, one that was never very attractive because of a well-established twined industry that provided a suite of forms predating the introduction of coiling in the region by more than four millennia (Adovasio 1986; Jolie 2004). ${ }^{5}$

In light of these observations, it may be that twined and coiled baskets offered functional equivalents for seed collecting and processing by foragers. The forms produced by these techniques for the purpose of small seed exploitation might be thought of as functionally isomorphic (Binford 1972:298-299), though this remains to be verified by experimental data. Of course, foragers could not have evaluated the relative merits of either technique unless both were present. Whereas the Southern and Northern Paiute knew of coiling but chose twining for their seed-processing equipment, the early occupants of Danger Cave may have only known twining. Initial adoption in large part would have depended on what was available at the time that the need for seed exploitation arose. In the eastern Great Basin, twining was clearly present before 8600 B.P. when small seed consumption began in earnest, but coiling does not yet appear to have this antiquity. Thus, the initial loads of pickleweed seed that were threshed and parched in Danger Cave may well have been processed with twined basketry trays. Direct evidence of pickleweed seed parching is indicated by at least 8160 B.P. by roasted seeds in coprolites (David Rhode, personal communication 2007; see also Rhode et al. 2006:Table 3) and, perhaps earlier during DI times, as suggested by the charcoal content of coprolites analyzed by Fry (1976:Table 6). Once the coiling technique became available for use, either because of independent invention or diffusion, then the relative merits of one technique over another could have been evaluated.

Invention in the eastern Great Basin seems unlikely based on the prior existence of a technology sufficient to the need: twining. There is no absolute measure for superiority with regard to seed processing and certainly any claims as such must be demonstrated by experimental data. Efficiency in use is only one concern; there are also the cost/benefit factors of production (Bettinger et al. 2006; Ugan et al. 2003). Even if one could experimentally demonstrate that coiled baskets are slightly sturdier than twined forms or more effective in parching, twined forms might be more efficiently made, thus superior for foragers who are time constrained (though production efficiency needs to be demonstrated). If coiling entailed production costs much greater than its benefits when compared to the already well-established and versatile twining traditions of the Great Basin, then it is unlikely to have been adopted (at least in the short run), and it is even more unlikely to have been invented in the midst of such a twining tradition.

The Colorado Plateau presents a different case, for although twining as a technique has great time depth for sandal production, this is not true for basketry. Unlike the Great Basin, we argue that a small seed adaptation on the Colorado Plateau must have emerged in the context of a coiled-basketry tradition, and this is what makes the small Cowboy Cave basket intriguing. This specimen has no obvious functional role in collecting, winnowing, or parching seeds. Its well-produced nature implies a strong tradition of this craft - it was no experiment or early learning effort. The Cowboy Cave basket hints at the possibility that there may not be a causal relationship between seed processing and the first 
development of coiled basketry. Coiled basketry may well have been invented for other reasons but was then adopted for the exploitation of small seeds, developing in-tandem after that point and being used almost exclusively for that purpose by Archaic foragers on the Colorado Plateau to maximize the nutritional benefits of relatively low-ranked small seeds. Such extensive subsequent use of the technology might mask its initial roles.

A convincing link between coiled basketry's origin and the development of seed processing requires additional direct radiometric assays on the earliest specimens of basketry, a greater understanding of variability in technique and form, and firm temporal placement for the beginning of small seed exploitation. Stemming from these points, there are two related observations worth reiterating about the technology and chronology of early coiling that have bearing on our understanding of the development of intensive seed processing. First, the available dates on coiled basketry are neither as numerous nor as precise as those available (and accumulating) for other corollaries of early Holocene subsistence economies from the Great Basin and Colorado Plateau. Radiocarbon assays may never close the gap between the earliest coiling and signs of intensive small seed use in the Great Basin, but this should not be true for the Colorado Plateau where alternative methods of rigid container fabrication seems to have been unknown. The second point is underscored by the form of the early Cowboy Cave basket. It is clearly not a parching tray and likely had nothing to do with small seed processing. The basket-handled scarifier from Hinds Cave and miniature plaque from Guilá Naquitz further demonstrate that not all early coiling was used expressly for parching or other aspects of harvesting seeds. This apparent diversity of forms very early on suggests that there may not be a causal relationship between seed processing and the development of coiled basketry, but this does not mean that coiling did not ultimately supply Archaic foragers with the means to augment preexisting seed processing strategies. The AMS determination on the recent Cowboy Cave find does not answer any questions about the development of coiled basketry technology directly, but it does remind us that coiled basketry's origins may not have a direct functional link to intensive seed harvesting and processing.

\section{Conclusions}

Early Archaic foragers on the Colorado Plateau clearly relied on small seeds for food (Hogan 1980; Van Ness and Hansen 1996), but did this occur as early as has been assumed? In the eastern Great Basin, Rhode et al. (2006:337) show that this was not the case. They also provide a proximal explanation for the shift to small seed use based on the evidence for dramatic shrinking of wetlands during the early Holocene (Grayson 1993; Oviatt et al. 2003), which diminished both high-ranked resources and high-quality resource patches. Such wetlands did not exist on the Colorado Plateau, or did so in very limited fashion compared to the Great Basin. Thus, Holocene drying might have had an earlier impact on high-ranked resources and highquality resource patches on the Colorado Plateau, especially in the dissected and broken landscape of the Canyonlands section. Indeed, the transition to xerophytic vegetation that prompted the dietary shift in the eastern Great Basin may have been time transgressive from south to north, such that the exploitation of low-ranked foods would have begun far earlier in the southern deserts of Mexico and the Southwest than in the Great Basin (Betancourt et al. 1990). This is a context in which coiledbasketry technology may have spread northward out of Mexico along with the exploitation of small seeds. Despite drying, the Sonoran Desert provides a rich bounty of food from columnar cacti, mesquite, and agave, items not available on the Colorado Plateau and not requiring baskets for effective harvesting and processing. As such, the use of basketry for small seed exploitation might still have begun on the Colorado Plateau, where the need to use such low-ranked resources may have been felt first.

This said, archaeologists may be mistaken to search for the origins of a technology in the functional role for which that technology later served and for which it was eminently suited. A current function could have little or nothing to do with a past function and to the original genesis of a technology or artifact form. The reasons behind the origins and initial spread of a trait or behavior could be distinct and should be analytically separated from the reasons that a trait or behavior was maintained in a population. Coiled baskets may be naturally useful for seed processing but it does not 
automatically follow therefore that coiled baskets were originally designed for this purpose. Coiled or twined trays for the collecting, winnowing, and parching of small seeds may be the result of a process of using an existing technology to create novel basketry forms suited to a new food exploitation strategy, thus representing a case of technological reconfiguration.

The complete one rod foundation basket sewn with non-interlocking stitches from Cowboy Cave that has been described here highlights the complexities attendant to teasing out details of the relationship between coiled basketry technology and small-seed exploitation. Exploring these issues and others will require much additional research and direct dating of the technology associated with small seed use and the organic residue from processing and consumption, specifically coprolites. Assessing the role of basketry in this significant dietary response to Holocene drying and the relative merits of coiling over twining will require not only a campaign of direct dating of ancient specimens across the entire Southwest, but also experimental research as to the relative efficiency and effectiveness of coiled vs. twined baskets in all aspects of seed exploitation weighed against the costs of producing utilitarian forms by both techniques. Through such research, basketry and other perishable artifacts can help address some of the big questions about the past.

Acknowledgments. We would like to thank Craig Harmon of the BLM for retrieving the basket and for securing funds to have a sample radiocarbon dated. The group present when the find was made included Annie Geib, Chuck and Charlie Larue, Greg and Karen Nunn, and Mick and Neville Robins. Duncan Metcalfe and Kathy Kankainen of the UMNH kindly facilitated our visit to study the basket. This paper benefited greatly from valuable comments made by W. H. Wills on an early draft of this paper and constructive criticism provided by J. M. Adovasio (multiple times), Tom Connolly, Oskar Burger, and two anonymous reviewers. We are indebted to Lisa Huckell for insights into potential botanical identifications, Larry Benson for discussions of early Holocene paleoclimate, Laurie A. Walsh and Laurie D. Webster for bibliographic input, and Alan Schroedl for the scan of his figure that provided the base for our Figure 6 . Kelly Graf and Ted Goebel made available the chronometric data from Bonneville Estates Rockshelter and Kelly kindly permitted us to cite her in press publication. Edward acknowledges generous funding from the Sundance Archaeological Research Fund, University of Nevada, Reno, for his preliminary work on the Bonneville Estates Rockshelter perishable artifact assemblage. Jorge Estrada generously provided assistance with the Spanish translation of the abstract.

\section{References Cited}

Adams, Jenny $L$.

1999 Refocusing the Role of Food-Grinding Tools as Correlates for Subsistence Strategies in the U.S. Southwest. American Antiquity 64:475-498.

Adovasio, J. M.

1970a The Origin, Development and Distribution of Western Archaic Textiles. Tebiwa 13:1-40.

1970b Textiles. In Hogup Cave, by C. Melvin Aikens, pp. 133-153. University of Utah Anthropological Papers 93. University of Utah Press, Salt Lake City.

1974 Prehistoric North American Basketry. In Collected Papers on Aboriginal Basketry, edited by Donald R. Tuohy and Doris L. Rendall, pp. 98-148. Anthropological Papers 16. Nevada State Museum, Carson City.

1977 Basketry Technology: A Guide to Identification and Analysis. Aldine Publishing Company, Chicago.

1980 Prehistoric Basketry of Western North America and Mexico. In Early Native Americans: Prehistoric Demography, Economy and Technology, edited by David L. Browman, pp. 341-362. Mouton, The Hague.

1986 Prehistoric Basketry. In Great Basin, edited by Warren L. d'Azevedo, pp. 194-205. Handbook of North American Indians, Vol. 11, William C. Sturtevant, general editor. Smithsonian Institution, Washington, D.C.

2003 Appendix D. Some Thoughts on the Chronology of Cueva Espontosa and the Cuatro Ciénegas Basin. In Sandals from Coahuila Caves, by Walter W. Taylor, edited by Nicholas J. Demerath, Mary C. Kennedy, and Patty Jo Watson, pp. 147-151. Studies in Pre-Columbian Art and Archaeology Number 35. Dumbarton Oaks Research Library and Collection, Washington, D.C.

Aikens, C. Melvin

1970 Hogup Cave. University of Utah Anthropological Papers No. 93. University of Utah Press, Salt Lake City.

Ambler, J. Richard

1996 Dust Devil Cave and Archaic Complexes of the Glen Canyon Area. In Glen Canyon Revisited, by Phil R. Geib, pp. 40-52. University of Utah Anthropological Papers 119. University of Utah Press, Salt Lake City.

Andrews, R. L., and J. M. Adovasio

1980 Perishable Industries from Hinds Cave, Val Verde County, Texas. Ethnology Monographs 5. Department of Anthropology, University of Pittsburgh, Pittsburgh.

Aschmann, Homer $\mathrm{H}$.

1952 A Primitive Food Preparation Technique in Baja California. Southwestern Journal of Anthropology 8:36-39.

Barlow, K. Renee, and Duncan Metcalfe

1996 Plant Utility Indices: Two Great Basin Examples. Journal of Archaeological Science 23:351-371.

Berry, Claudia F., and Michael S. Berry

1986 Chronological and Conceptual Models of the Southwestern Archaic. In Anthropology of the Desert West: Essays in Honor of Jesse D. Jennings, edited by Carol J. Condie and Don D. Fowler, pp. 253-327. University of Utah Anthropological Papers No. 110. University of Utah Press, Salt Lake City.

Betancourt, Julio L., Thomas R. Van Devender, and Paul S. Martin (editors)

1990 Packrat Middens: The Last 40,000 Years of Biotic Change. University of Arizona Press, Tucson.

Bettinger, Robert L., and Martin A. Baumhoff 
1982 The Numic Spread: Great Basin Cultures in Competition. American Antiquity 47:485-503.

Bettinger, Robert L., Bruce Winterhalder, and Richard McElreath

2006 A Simple Model of Technological Intensification. Journal of Archaeological Science 33:538-545.

Binford, Lewis R.

1972 "Red Ochre" Caches from the Michigan Area: A Possible Case of Cultural Drift. In An Archaeological Perspective, by Lewis R. Binford, pp. 295-313. Seminar Press, New York.

Bock, Walter J.

1959 Preadaptation and Multiple Evolutionary Pathways. Evolution 13:194-211.

Cane, Scott

1989 Australian Aboriginal Seed Grinding and its Archaeological Record: A Case Study from the Western Desert. In Foraging and Farming: The Evolution of Plant Exploitation, edited by David R. Harris and Gordon C. Hillman, pp. 99-119. Unwin Hyman, London.

Cleland, Charles E.

1966 The Pleistocene Animal Ecology and Ethnozoology of the Upper Great Lakes Region. Anthropology Papers No. 9. Museum of Anthropology, University of Michigan, Ann Arbor.

Conn, Richard G., and Mary Dodds Schlick

1998 Basketry. In Plateau, edited by Deward E. Walker, pp. 600-610. Handbook of North American Indians, Vol. 12, William C. Sturtevant, general editor. Smithsonian Institution, Washington, D.C.

Connolly, Thomas J.

2006 Implications of New Radiocarbon Ages on Coiled Basketry from the Northern Great Basin. Paper presented at the 30th Great Basin Anthropological Conference, Las Vegas, Nevada.

Connolly, Thomas J., and Pat Barker

2004 Basketry Chronology of the Early Holocene in the Northern Great Basin. In Early and Middle Holocene Archaeology of the Northern Great Basin, edited by Dennis L. Jenkins, Thomas J. Connolly, and C. Melvin Aikens, pp. 241-250. University of Oregon Anthropological Papers 62. University of Oregon, Eugene.

Coulam, Nancy J.

1988 Intermountain Archaic Subsistence and an Archaeobotanical Analysis of Swallow Shelter and Remnant Cave. Unpublished Ph.D. Dissertation, Arizona State University, Tempe.

Cressman, Luther S.

1942 Archaeological Researches in the Northern Great Basin. Carnegie Institution of Washington Publication 538. Carnegie Institution of Washington, Washington D.C.

1986 Prehistory of the Northern Area. In Great Basin, edited by Warren L. d'Azevedo, pp. 120-126. Handbook of North American Indians, Vol. 11, William C. Sturtevant, general editor. Smithsonian Institution, Washington, D.C.

Dodge, James E.

1980 Ground Stone. In Cowboy Cave, by Jesse D. Jennings, pp. 113-116. University of Utah Anthropological Papers No. 104. University of Utah Press, Salt Lake City.

Driver, Harold E., and William C. Massey

1957 Comparative Studies of North American Indians. Transactions of the American Philosophical Society Volume 47, Part 2. The American Philosophical Society, Philadelphia.

Elsasser, Albert B.

1978 Basketry. In California, edited by Robert F. Heizer, pp. 626-641. Handbook of North American Indians, Vol.
8, William C. Sturtevant, general editor. Smithsonian Institution, Washington, D.C.

Flannery, Kent V.

1969 Origins and Ecological Effects of Early Domestication in Iran and the Near East. In Domestication and Exploitation of Plants and Animals, edited by Peter Ucko, Ruth Tringham, and G. W. Dimbleby, pp. 73-100. Duckworth, London.

Fowler, Catherine $\mathrm{S}$.

1996 Eastern North American Textiles: A Western Perspective. In A Most Indispensable Art: Native Fiber Industries from Eastern North America, edited by James B. Petersen, pp. 180-199. University of Tennessee Press, Knoxville.

Fowler, Catherine S., and Lawrence E. Dawson

1986 Ethnographic Basketry. In Great Basin, edited by Warren L. d'Azevedo, pp. 705-737. Handbook of North American Indians, Vol. 11, William C. Sturtevant, general editor. Smithsonian Institution, Washington, D.C.

Fowler, Catherine S., Eugene M. Hattori, and Amy J. Dansie

2000 Ancient Matting from Spirit Cave, Nevada: Technical Implications. In Beyond Cloth and Cordage: Archaeological Textile Research in the Americas, edited by Penelope Ballard Drooker and Laurie D. Webster, pp. 119-139. University of Utah Press, Salt Lake City.

Fry, Gary F.

1976 Analysis of Prehistoric Coprolites from Utah. University of Utah Anthropological Papers 97 . University of Utah Press, Salt Lake City.

Geib, Phil R.

1996a AMS Dating of Plain-Weave Sandals from the Central Colorado Plateau. Utah Archaeology 9:35-53.

1996b Glen Canyon Revisited. University of Utah Anthropological Papers 119. University of Utah Press, Salt Lake City.

2000 Sandal Types and Archaic Prehistory on the Colorado Plateau. American Antiquity 65:509-524.

Gould, Richard A

1969 Yiwara: Foragers of the Australian Desert. Charles Scribner's Sons, New York.

Gould, Stephen J., and Elisabeth S. Vrba

1982 Exaptation-A Missing Term in the Science of Form. Paleobiology 8:4-15.

Graf, Kelly E.

2007 Stratigraphy and Chronology of the Pleistocene to Holocene Transition at Bonneville Estates Rockshelter Eastern Great Basin. In Paleoindian or Paleoarchaic? Great Basin Human Ecology at the Pleistocene-Holocene Transition, edited by Kelly E. Graf and David N. Schmitt. University of Utah Press, Salt Lake City, in press.

Grayson, Donald K

1993 The Desert's Past: A Natural Prehistory of the Great Basin. Smithsonian Institution Press, Washington, D.C.

Gremillion, Kristen J.

2004 Seed Processing and the Origins of Food Production in Eastern North America. American Antiquity 69:215-233.

Hattori, Eugene M., and Catherine S. Fowler

2005 Early Fiber Technologies and Fiber Research in the Western Great Basin. Paper presented at the $70^{\text {th }}$ Annual Meeting of Society for American Archaeology, Salt Lake City, Utah

Heizer, Robert F., and Alex D. Krieger

1956 The Archaeology of Humboldt Cave, Churchill County, Nevada. University of California Publications in American Archaeology and Ethnology 47(1). University of California Press, Berkeley. 
Hewitt, Nancy J.

1980 Fiber Artifacts. In Cowboy Cave, by Jesse D. Jennings, pp. 49-74. University of Utah Anthropological Papers No. 104. University of Utah Press, Salt Lake City.

Hogan, Patrick F.

1980 Appendix IX: The Analysis of Human Coprolites from Cowboy Cave. In Cowboy Cave, by Jesse D. Jennings, pp. 201-211. University of Utah Anthropological Papers No. 104. University of Utah Press, Salt Lake City.

Huckell, Bruce B.

1996 The Archaic Prehistory of the North American Southwest. Journal of World Prehistory 10:305-373.

Hyland, D. C., J. M. Adovasio, and J. S. Illingworth

2003 The Perishable Artifacts. In Pendejo Cave, edited by Richard S. MacNeish and Jane G. Libby, pp. 297-416. University of New Mexico Press, Albuquerque.

Jennings, Jesse D.

1957 Danger Cave. University of Utah Anthropological Papers 27. University of Utah Press, Salt Lake City.

1978 Prehistory of Utah and the Eastern Great Basin. University of Utah Anthropological Papers 98. University of Utah Press, Salt Lake City.

1980 Cowboy Cave. University of Utah Anthropological Papers 104. University of Utah Press, Salt Lake City.

Jolie, Edward A.

2004 Coiled Basketry from Charlie Brown Cave, Western Nevada. Unpublished M.A. thesis, Department of Anthropology, University of Nevada, Reno.

2006 The Technomechanics of Plains Indian Coiled Gambling Baskets. Plains Anthropologist 51:17-49.

Jolie, Edward A., and Ruth B. Burgett

2002 Perishable Artifacts from Bonneville Estates Rockshelter, Elko County, Nevada. Paper presented at the 28th Great Basin Anthropological Conference, Elko, Nevada.

Jolie, Edward A., and Eugene M. Hattori

2005 The Spread of Coiled Basketry in the Prehistoric Great Basin. Paper presented at the 70th Annual Meeting of Society for American Archaeology, Salt Lake City, Utah.

Jones, Kevin T., and David B. Madsen

1989 Calculating the Cost of Resource Transportation: A Great Basin Example. Current Anthropology 30:529-534.

King, Mary Elizabeth

1965 Textiles and Basketry of the Paracas Period, Ica Valley, Peru. Unpublished Ph.D. dissertation, Department of Anthropology, University of Arizona, Tucson.

1979 The Prehistoric Textile Industry of Mesoamerica. In The Junius B. Bird Pre-Columbian Textile Conference, 1973, edited by Ann Pollard Rowe, Elizabeth P. Benson, and Anne-Louise Schaffer, pp. 265-278. Textile Museum and Dunbarton Oaks, Washington, D.C.

1986 Preceramic Cordage and Basketry from Guilá Naquitz. In Guilá Naquitz: Archaic Foraging and Early Agriculture in Oaxaca, Mexico, edited by Kent V. Flannery, pp. 157-161. Academic Press, San Diego.

Lindsay, Alexander J., J. Richard Ambler, Mary Anne Stein, and Philip M. Hobler

1968 Survey and Excavations North and East of Navajo Mountain, Utah, 1959-1962. Glen Canyon Series 8, Museum of Northern Arizona Bulletin 45. Museum of Northern Arizona, Flagstaff.

Long, A., B. F. Benz, D. J. Donahue, A. J. T. Jull, and L. J. Toolin 1989 First Direct AMS Dates on Early Maize from Tehuacán, Mexico. Radiocarbon 31:1035-1040.

Loud, Llewellyn L., and M. R. Harrington

1929 Lovelock Cave. University of California Publications in American Archaeology and Ethnology Vol. 25, No. 1. University of California Press, Berkeley.
MacNeish, Richard S.

1958 Preliminary Archaeological Investigations in the Sierra de Tamaulipas, Mexico. Transactions of the American Philosophical Society Vol. 48, No. 6. The American Philosophical Society, Philadelphia.

MacNeish, Richard S., Antoinette Nelken-Terner, and Irmgard W. Johnson

1967 The Prehistory of the Tehuacan Valley, Vol. 2, The NonCeramic Artifacts. University of Texas Press, Austin.

Madsen, David B., and David Rhode (editors)

1994 Across the West: Human Population Movement and the Expansion of the Numa. University of Utah Press, Salt Lake City.

Mason, Otis Tufton

1904 Aboriginal American Basketry: Studies in a Textile Art Without Machinery. In Annual Report of the U.S. National Museum for 1901-1902, pp. 171-548. Government Printing Office, Washington, D.C.

McGregor, Roberta

1992 Prehistoric Basketry of the Lower Pecos, Texas. Monographs in World Archaeology No. 6. Prehistory Press, Madison, Wisconsin.

Morris, Earl H., and Robert F. Burgh

1941 Anasazi Basketry, Basket Maker II Through Pueblo III: A Study Based on Specimens from the San Juan River County. Carnegie Institution of Washington Publication 533. Carnegie Institution of Washington, Washington, D.C.

O'Connell, James F., and Kristin Hawkes

1981 Alyawara Plant Use and Optimal Foraging Theory. In Hunter-Gatherer Foraging Strategies: Ethnographic and Archeological Analyses, edited by Bruce Winterhalder and Eric Alden Smith, pp. 99-125. University of Chicago Press, Chicago.

O'Connell, James F., Kevin T. Jones, and Steven R. Simms 1982 Some Thoughts on Prehistoric Archaeology in the Great Basin. In Man and Environment in the Great Basin, edited by D.B. Madsen and J.F. O'Connell, pp. 227-240. SAA Papers No. 2. Society for American Archaeology, Washington, D.C.

O’Neale, Lila M.

1949 Basketry. In The Comparative Ethnology of South American Indians, edited by Julian H. Steward, pp. 69-96. Handbook of South American Indians, Vol. 5, Bureau of American Ethnology Bulletin 143. Government Printing Office, Washington, D.C.

Oviatt, Charles G., David B. Madsen, and Dave N. Schmitt

2003 Late Pleistocene and Early Holocene Rivers and Wetlands in the Bonneville Basin of Western North America. Quaternary Research 60:200-210.

Pearsall, Deborah

2000 Paleoethnobotany: A Handbook of Procedures. Academic Press, San Diego.

Pérez de Micou, Cecilia

2001 Cestería y Cordelería para los Muertos. Chungará 33:137-144.

Piperno Dolores R., and Irene Holst

1998 The Presence of Starch Grains on Prehistoric Stone Tools from the Humid Neotropics: Indications of Early Tuber Use and Agriculture in Panama. Journal of Archaeological Science 25:765-776.

Rhode, David, David B. Madsen, and Kevin T. Jones

2006 Antiquity of Early Holocene Small-seed Consumption and Processing at Danger Cave. Antiquity 80:328-339.

Roth, Walter Edmund

1901 Food: Its Search, Capture, and Preparation. North Queensland Ethnography Bulletin 3:7-34.

Rowe, Marvin W. 
2001a Physical and Chemical Analysis. In Handbook of Rock Art Research, edited by David S. Whitley, pp. 190-220. AltaMira Press, Walnut Creek, California.

2001b Dating by AMS Radiocarbon Analysis. In Handbook of Rock Art Research, edited by David S. Whitley, pp. 139-166. AltaMira Press, Walnut Creek, California.

Rudy, Sara Sue

1957 Textiles. In Danger Cave, by Jesse D. Jennings, pp. 235-264. University of Utah Anthropological Papers No. 27. University of Utah Press, Salt Lake City.

Schroedl, Alan R.

1976 The Archaic of the Northern Colorado Plateau. Ph.D. dissertation, University of Utah, Salt Lake City. University Microfilms, Ann Arbor.

Schroedl, Alan R., and Nancy J. Coulam

1994 Cowboy Cave Revisited. Utah Archaeology 7:1-34.

Simms, Steven R.

1985 Acquisition Cost and Nutritional Data on Great Basin Resources. Journal of California and Great Basin Anthropology 7:117-126.

1987 Behavioral Ecology and Hunter-Gatherer Foraging. BAR International Series 381. British Archaeological Reports, Oxford.

Spier, Leslie

1930 Klamath Ethnography. University of California Publications in American Archaeology and Ethnology Vol. 30. University of California Press, Berkeley.

Stahl, Ann B.

1984 Hominid Dietary Selection Before Fire. Current Anthropology 25:151-168.

1989 Plant-Food Processing: Implications for Dietary Quality. In Foraging and Farming: The Evolution of Plant Exploitation, edited by David R. Harris and Gordon C. Hillman, pp. 171-194. Unwin Hyman, London.

Stuiver, M., P. J. Reimer, E. Bard, J. W. beck, G. S. Burr, K. A Hughen, B. Kromer, F. G. McCormac, J. Plicht, and M. Spurk

1998 INTCAL98 Radiocarbon Age Calibration 24,000-0 BP. Radiocarbon 40:1041-1083.

Taylor, Walter W.

1966 Archaic Cultures Adjacent to the Northeastern Frontiers of Mesoamerica. In Archaeological Frontiers and External Connections, edited by Gordon F. Elkholm and Gordon R. Willey, pp. 59-94. Handbook of Middle American Indians, Vol. 4, Robert Wauchope, general editor. University of Texas Press, Austin.

Van Ness, Margaret A., and Eric Hansen

1996 Archaic Subsistence in the Glen Canyon Region. In Glen Canyon Revisited, by Phil R. Geib, pp. 117-125. Anthropological Papers No. 119. University of Utah Press, Salt Lake City.

Ugan, Andrew, Jason Bright, and Alan Rogers

2003 When is Technology Worth the Trouble? Journal of Archaeological Science 30:1315-1329.

Wright, Katherine I.
1994 Ground-stone Tools and Hunter-Gatherer Subsistence in Southwest Asia: Implications for the Transition to Farming. American Antiquity 59:238-263.

\section{Notes}

1. As Stahl (1989:181-182) points out, heat treatment is often associated with nutrient loss, but with the exception of overcooking, the majority of this loss occurs during cooking in water. Even then, the nature and extent of nutrient loss depends on a number of factors including the temperature and $\mathrm{pH}$ of the cooking water, food form, temperature, and cooking time. Dry heat actually minimizes the loss of watersoluble vitamins and minerals.

2. In apparent contrast to North America and Mexico, coiling appears to have been a minority basketweaving technique throughout most of South America, being common mainly on the coasts of Chile and Peru and in Tierra del Fuego (O'Neale 1949). However, baskets produced in the latter region are technologically unique and bear little resemblance to coiling made elsewhere in the Americas. In general, archaeological coiled basketry from South America, though scarce and poorly reported, all appears to date later than the early Holocene (e.g., King 1965; Pérez de Micou 2001).

3. To our knowledge, direct dating of grinding tools has not yet been performed but is certainly within the realm of possibility these days for tools from dry shelters because of the plasma oxidation method pioneered by Rowe (2001b).

4. Prior to the discovery of the Cowboy Cave basket, Jolie had initiated a program to directly AMS date early coiled basketry from western North America and sampled six of the seven fragments from Strata IIb and IIIg-IIIh at Cowboy Cave. Reanalysis of these specimens is in progress, but newly returned AMS determinations confirm that the complete basket described here is the oldest example from the site by several hundred radiocarbon years. A future publication will present the results of these new dates and technological reanalyses.

5. The Washoe, who have a mixed twined and coiled basketry industry (Fowler and Dawson 1986), further complicate this argument. However, one plausible explanatory scenario might see the exclusively twined plant harvesting toolkit as a Numic innovation (see Bettinger and Baumhoff 1982:496-497) that was probably adopted relatively recently by the Washoe over several centuries of intermarriage and shared subsistence pursuits. Unfortunately, at this time, the complete absence of any archaeological basketry from historic Washoe territory prohibits us from evaluating this and most other ideas about the origin of the mixed Washoe basketry industry. 